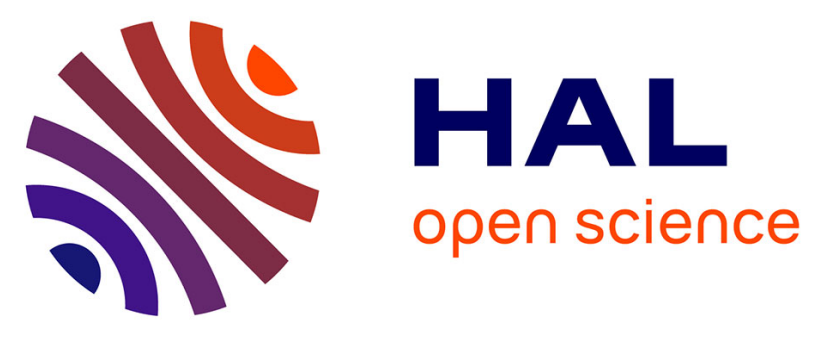

\title{
Accumulation and transmission of alphasatellite, betasatellite and Tomato yellow leaf curl virus in susceptible and Ty-1-resistant tomato plants
}

Deborah Conflon, Martine Granier, Fidèle Tiendrébéogo, Pascal Gentit, Michel Peterschmitt, Cica Urbino

\section{To cite this version:}

Deborah Conflon, Martine Granier, Fidèle Tiendrébéogo, Pascal Gentit, Michel Peterschmitt, et al.. Accumulation and transmission of alphasatellite, betasatellite and Tomato yellow leaf curl virus in susceptible and Ty-1-resistant tomato plants. Virus Research, 2018, 253, pp.124-134. 10.1016/j.virusres.2018.06.003 . hal-02623258

\section{HAL Id: hal-02623258 \\ https://hal.inrae.fr/hal-02623258}

Submitted on 26 May 2020

HAL is a multi-disciplinary open access archive for the deposit and dissemination of scientific research documents, whether they are published or not. The documents may come from teaching and research institutions in France or abroad, or from public or private research centers.
L'archive ouverte pluridisciplinaire HAL, est destinée au dépôt et à la diffusion de documents scientifiques de niveau recherche, publiés ou non, émanant des établissements d'enseignement et de recherche français ou étrangers, des laboratoires publics ou privés.

\section{(ㅇ)(1) $\$$}

Distributed under a Creative Commons Attribution - NonCommercial - NoDerivatives 44.0 
Accumulation and transmission of alphasatellite, betasatellite and Tomato yellow leaf curl virus in susceptible and $T y$-1-resistant tomato plants

Déborah CONFLON ${ }^{\mathrm{a}, \mathrm{b}}$, Martine GRANIER ${ }^{\mathrm{a}, \mathrm{b}}$, Fidèle TIENDREBEOGO ${ }^{\mathrm{c}, \mathrm{d}}$, Pascal GENTIT ${ }^{\mathrm{e}}$ Michel PETERSCHMITT ${ }^{\mathrm{a}, \mathrm{b}}$ and Cica URBINO ${ }^{\mathrm{a}, \mathrm{b}}$

${ }^{a}$ CIRAD, UMR BGPI, F-34398 Montpellier, France

${ }^{\mathrm{b}}$ BGPI, Univ Montpellier, CIRAD, INRA, Montpellier SupAgro Montpellier, France

${ }^{c}$ Laboratoire de Virologie et de Biotechnologies Végétales (LVBV), INERA, 01 BP 476 Ouagadougou 01, Burkina Faso

${ }^{\mathrm{d}}$ Laboratoire Mixte International Patho-Bios, IRD-INERA, 01 BP 476 Ouagadougou 01, Burkina Faso

e ANSES, Plant Health Laboratory, Unité de Bactériologie, Virologie et détection des OGM, 7 rue Jean Dixméras, 49044 Angers Cedex 01, FRANCE

*Corresponding author: Cica URBINO

Address: CIRAD, UMR BGPI, Campus International de Baillarguet, 34398, Montpellier Cedex 5, France, Phone: 334996248 47, Email: cica.urbino@ cirad.fr.

\section{Highlights}

- DNA satellites accumulate at higher level than TYLCV in tomato plants

- DNA satellites are maintained with TYLCV up to 5 months in tomato plants

- DNA satellites are efficiently transmitted with TYLCV to tomato plants

- The resistance provided by the $T y-1$ gene is partially overcomed by a betasatellite 


\section{ABSTRACT}

Begomoviruses (family Geminiviridae) are frequently associated with alphasatellites and betasatellites in the Old World. Tomato yellow leaf curl virus, one of the most damaging begomovirus species worldwide, was recently found associated with betasatellites in the eastern coast of the Mediterranean Sea, and in the Middle East region. Tomato yellow leaf curl virus (TYLCV)/betasatellite associations were shown to increase TYLCV virulence in experimental conditions. The sustainability of TYLCV/satellite associations in tomato was assessed here by estimating accumulation levels of satellites in comparison to TYLCV, vector transmission efficiency, and by testing how far the popular $T y-1$ resistance gene used in most TYLCV-resistant tomato cultivars in the Mediterranean Basin is effective against betasatellites. Three satellites previously isolated from okra in Burkina Faso-of the species Cotton leaf curl Gezira betasatellite,, Cotton leaf curl Gezira alphasatellite and Okra leaf curl Burkina Faso alphasatellite - were shown to accumulate at levels similar to, or higher than, the helper virus TYLCV-Mld in tomato plants from 32 to 150 days post inoculation (dpi). Cotton leaf curl Gezira betasatellite (CLCuGB) reduced TYLCV-Mld accumulation whereas alphasatellites did not. Transmission tests were performed with $B$. tabaci from plants infected with TYLCV-Mld/CLCuGB- or TYLCV-Mld/Okra leaf curl Burkina Faso alphasatellite. At $32 \mathrm{dpi}$, both satellites were transmitted to more than $50 \%$ of TYLCVinfected test plants. Betasatellite transmission, tested further with 150 dpi source plants was successful in more than $30 \%$ of TYLCV-infected test plants. Ty-1 resistant tomato plants coinfected with TYLCV (-Mld or -IL) and CLCuGB exhibited mild leaf curling and mosaic symptoms at the early stage of infection associated with a positive effect on TYLCV-IL accumulation, while resistant plants infected with TYLCV only, were asymptomatic. Together with previous experimental studies, these results further emphasize the potential risk of betasatellites to tomato cultivation, including with $T y-1$ resistant cultivars.

Keywords: begomovirus, Geminiviridae, DNA satellites, real time PCR, Bemisia tabaci 


\section{INTRODUCTION}

Viruses of the genus Begomovirus are circular single-stranded plant DNA viruses belonging to the family Geminiviridae, and are transmitted by the whitefly Bemisia tabaci (Zerbini et al., 2017). Their genome consists either of two components of about $2.6 \mathrm{~kb}$ (DNAA and DNA-B components) or a single A-like component (Dry et al., 1993; Kheyr-Pour et al., 1991; Navot et al., 1991). Monopartite begomoviruses are often associated with alphasatellites or betasatellites, two types of circular ssDNA molecules of about $1.3 \mathrm{~kb}$, detected mainly in Asia and Africa (Briddon and Stanley, 2006; Zhou, 2013). These complexes can cause important economic damage to crops.

The only sequence homology between begomovirus and betasatellite DNAs is within the conserved hairpin structure of begomovirus genomes (Briddon et al., 2001) that is required for rolling-circle replication (Heyraud-Nitschke et al., 1995; Laufs et al., 1995). Begomoviruses assist betasatellites for replication, and encapsidation (Dry et al., 1993; Saunders et al., 2000) with no strict specificity (Saunders et al., 2008). Betasatellite genome encodes the multifunctional protein $\beta \mathrm{C} 1$, which was reported to enhance symptom expression (Cui et al., 2004; Saunders et al., 2004), to suppress transcriptional gene silencing (TGS) (Yang et al., 2011b) and post transcriptional gene silencing (PTGS) (Amin et al., 2011; Cui et al., 2005), and to be involved in virus movement (Patil and Fauquet, 2010; Saeed et al., 2007). For some begomovirus species, e.g., Cotton leaf curl virus, Tomato yellow leaf curl China virus or Ageratum yellow vein virus, betasatellites are required for the expression of wild-type symptoms in their natural host plant (Cui et al., 2004; Mansoor et al., 1999). Betasatellites generally enhance virus accumulation (Jyothsna et al., 2013; Kon et al., 2009; Kumar et al., 2013; Saunders et al., 2000; Tiwari et al., 2010), but in some cases have no effect (Ranjan et al., 2014; Wu et al., 2011; Zhang et al., 2009). The accumulation and whitefly transmission of tomato leaf curl New Delhi virus (ToLCNDV) DNA was increased in the presence of the cotton leaf curl Multan betasatellite (CLCuMB) (Sivalingam and Varma, 2012).

The alphasatellite genome encodes a replication-associated protein (alpha-Rep) that resembles the Rep protein of nanoviruses (Mansoor et al., 1999; Saunders and Stanley, 1999). Alphasatellites are autonomous for their replication (Mansoor et al., 1999; Saunders and Stanley, 1999), but depend on a helper begomovirus for encapsidation, systemic infection and insect transmission. The effect of alphasatellites on helper virus is much less pronounced than that of betasatellites. Indeed, modulation of virus symptoms has been reported only rarely 
(Idris et al., 2011; Wu and Zhou, 2005) and the impact on virus accumulation is generally low or not detected (Briddon et al., 2004; Kumar et al., 2015; Kumar et al., 2014). However, in a few instances, alphasatellites have been reported to induce a significant decrease in virus (Kon et al., 2009; Saunders et al., 2002; Wu and Zhou, 2005) and betasatellite accumulations (Idris et al., 2011; Kon et al., 2009; Wu and Zhou, 2005). Two alphasatellites, Gossypium darwinii symptomless alphasatellite and Gossypium mustelinium symptomless alphasatellite, have been shown to have strong gene silencing activities (Nawaz-ul-Rehman et al., 2010) and recently, alpha-Rep proteins of seven genetically different alphasatellite genomes were shown to restore the expression of a transcriptionally silenced GFP transgene in Nicotiana benthamiana (Abbas et al., 2017). These results suggest that alphasatellites are involved in overcoming host defense which could explain their frequent association with begomovirus/betasatellites complexes (Briddon et al., 2004; Xie et al., 2010).

Tomato yellow leaf curl virus is responsible for major damage in tomato crops worldwide (Moriones and Navas-Castillo, 2000). It was shown to originate in the Middle East (Lefeuvre et al., 2010), and seven strains are reported (Zerbini et al., 2017). The most widely distributed strains are the type strain of tomato yellow leaf curl virus (hereafter TYLCV-IL) and the Mild strain (TYLCV-Mld), which are predominant in the Mediterranean basin. The first report of natural association of TYLCV with a DNA satellite was from Oman where two tomato plants were found to be coinfected with TYLCV-OM (previously called ToLCOMV), TYLCV-Ir (previously called TYLCV-OM), tomato leaf curl betasatellite (ToLCB) and Ageratum yellow vein Singapore alphasatellite, and four plants with TYLCV-Ir and ToLCB (Idris et al., 2011; Khan et al., 2008). Other associations were detected in tomato in Jordan, Saudi Arabia and probably Egypt with isolates of Cotton leaf curl Gezira betasatellite (AbdelSalam et al., 2017; Anfoka et al., 2014; Sohrab et al., 2017), and in Japan with Sida yellow vein China alphasatellite in a few samples of tomato (Shahid et al., 2014) and Cucurbita maxima (Shahid et al., 2015). Experimentally, TYLCV was shown to be a helper of any of the various betasatellites with which it was co-inoculated (Ito et al., 2009; Kon et al., 2009; Ueda et al., 2012; Zhang et al., 2009), and, most importantly, all of them increased its virulence. In view of these results, the introduction of betasatellites into western Mediterranean countries where satellites have never been reported is a potential threat to tomato cultivation.

The threat may be important if TYLCV/satellite associations are maintained in a sustainable way in the environment. As the sampling efforts in Middle Eastern countries are presently too limited to reveal if TYLCV-satellite associations are transient or not, it is 
proposed to address this question with experimentally infected plants, in which the accumulation level of viruses and satellites were monitored over time in comparison with that of TYLCV, and from which transmission efficiency of satellites was determined. Although it is known that alphasatellites and betasatellites can be assisted by various TYLCV strains in tomato plants and transmitted by B. tabaci (Ueda et al., 2012), with some impact on the accumulation of the helper virus, their accumulation level has not been compared so far to that of the helper virus during the infection course. Another factor that may determine the seriousness of the betasatellite threat is its potential capacity to overcome the popular $T y-1$ resistance gene that is used in virtually all TYLCV-resistant tomato cultivars in the Mediterranean countries.

Experimental studies were conducted with TYLCV-Mld and TYLCV-IL as helper viruses, and three satellites from Burkina Faso: Cotton leaf curl Gezira betasatellite, and two alphasatellites, isolated from okra plants infected with Cotton leaf curl Gezira virus (Tiendrébéogo et al., 2010). It is noteworthy that Cotton leaf curl Gezira betasatellite $(\mathrm{CLCuGB})$ has been reported previously in tomato plants infected with TYLCV (Anfoka et al., 2014). The two alphasatellite species are Cotton leaf curl Gezira alphasatellite and Okra leaf curl Burkina Faso alphasatellite. Although they were isolated from the same host species and country, their genomes exhibited $48 \%$ nucleotide divergence. The three satellites were inoculated with TYLCV-Mld in different combinations to susceptible tomato plants. Accumulation levels of virus and satellites were estimated by quantitative PCR (qPCR) in leaf samples collected between 11 and 150 days post inoculation (dpi), and compared to each other within and between treatments. The efficiency of transmission was estimated at 32 and $150 \mathrm{dpi}$ for CLCuGB and at $32 \mathrm{dpi}$ for OLCBFA. The capacity of TYLCV-Mld and TYLCVIL to maintain the betasatellite was studied in a susceptible and a $T y-1$ resistant cultivar by estimating their respective accumulations during infection.

\section{MATERIALS AND METHODS}

\subsection{Viruses and DNA satellites}

TYLCV-Mld (TYLCV-Mld[RE:02] accession no. AJ865337) isolated from tomato plants (Solanum lycopersicum L.) in Réunion island (Delatte et al., 2005) was tested as helper virus with three DNA satellites isolated from okra in Burkina Faso (Tiendrébéogo et al., 2010): the betasatellite CLCuGB (CLCuGB-[BF:Kap:Ok1-2:08], FN554575), and two alphasatellites, cotton leaf curl Gezira alphasatellite (CLCuGA-[BF:Kap:Ok7:08], FN554580) 
and okra leaf curl Burkina Faso alphasatellite (OLCBFA-[BF:Pô:Ok1:08], FN554581) The clone TYLCV-[IL-RE:STG4 :04], (AM409201) was tested as helper virus with CLCuGB.

Agroinfectious clones of TYLCV-IL and TYLCV-Mld have been described in Belabess et al., 2016 and Delatte et al., 2005 respectively. The full length genomes of alphasatellites and betasatellites were released from their PGEMT-easy vector by restriction enzyme digestion (Pst I for CLCuGB and CLCuGA and BamHI for OLCBFA) and ligated as a tandem repeat into the corresponding restriction site of pCambia 2300. Agrobacterium tumefaciens strain C58 MP90 was transformed with each of the recombinant plasmids by electroporation.

\subsection{Plant inoculation, experimental design, and growth conditions}

Fourteen-day-old tomato plants of the susceptible tomato cv. 'Monalbo' were agroinoculated with various combinations of agroinfectious clones as described in Table 1 (Experiments 1 to 3). Moreover, 14-day-old tomato plants of a $T y-1$ resistant cultivar (Pristyla, Gautier Semences) and a nearly isogenic susceptible cultivar (Gautier Semences) (Belabess et al., 2016) were agroinoculated with TYLCV-IL or TYLCV-Mld, alone or with CLCuGB (Table 1, Experiments 4 and 5). Agrobacteria cultures containing the infectious genomes were prepared for single and mixed infections as described in Belabess et al., 2016: the bacterial concentration of each recombinant plasmid was the same in inocula of mixed and of single infections. Controls consisted of plants agroinoculated with an empty plasmid.

Tomato plants were agroinfiltrated in cotyledons as described in Belabess et al., 2016. Five independent experiments were conducted (Table 1) in P3-level growth chambers to prevent environmental release. Plants arranged in a complete randomized block design were grown under $14 \mathrm{~h}$ light at $26 \pm 2^{\circ} \mathrm{C}$, and $10 \mathrm{~h}$ dark at $24 \pm 2^{\circ} \mathrm{C}$ and watered with 15:10:30 NPK fertilizer added with oligoelements. They were pruned regularly after $32 \mathrm{dpi}$ because of the limited space in the climatic chambers.

\subsection{Extraction of total DNA}

Leaf samples were collected from the youngest leaves as described in Belabess et al., 2016, and total DNA from each sample was extracted as described in Urbino et al., 2013, and stored at $-20^{\circ} \mathrm{C}$ until use.

\subsection{PCR amplification and sequencing}


Specific primers located on both sides of the origin of replication were designed to amplify $95 \%$ of the genome of CLCuGA (Suppl. Table 1). Complete genomes of CLCuGB were amplified with the pair of abutting primers previously designed for the detection of betasatellites (Briddon et al., 2002). The DNA extracts of two to four plants were used to amplify each satellite at each sampling date. Conditions for PCR amplification are given in Suppl. Table 1. PCR products were resolved on a $1 \%$ agarose gel and visualized with ethidium bromide staining. Major amplicons obtained with these primers pairs were isolated from agarose gel and sequenced with the primers used for PCR amplification.

\subsection{Quantitative PCR conditions}

Each DNA sample was tested in duplicate using the LightCycler 480 SYBR green I Master qPCR mix (Roche, Germany). Two microliters of a 1/100 dilution of total DNA extract of each plant sample was added to $5 \mu \mathrm{L}$ qPCR mix (LightCycler 480 SYBR Green I Master, Roche, Germany) in a final volume of $10 \mu \mathrm{L}$. Primers used for the amplification were targeted to the AC2/AC3 region for TYLCV-IL and TYLCV-Mld, the $\beta C 1$ gene for CLCuGB, and the alpha-Rep gene for CLCuGA and OLCBFA (Suppl. Table 1). Primers were used at $300 \mathrm{nM}$; cycling parameters were $95^{\circ} \mathrm{C}$ for $10 \mathrm{~min}$ followed by 40 cycles of $10 \mathrm{~s}$ at $95^{\circ} \mathrm{C}, 20 \mathrm{~s}$ at the annealing temperature (see Suppl. Table 1), and $20 \mathrm{~s}$ at $72^{\circ} \mathrm{C}$. Plant DNA of each extract was quantified by qPCR using the nuclear-encoded large subunit ribosomal RNA gene (Solanum lycopersicum L. 25S ribosomal RNA gene) as target.

All PCR fluorescence data were analyzed using the 2nd derivative max function of the LightCycler480 Software and the program LinRegPCR, (Ruijter et al., 2009) coupled to Pfaffl's quantification model (Pfaffl, 2001) as described in Belabess et al., 2016. The mean PCR efficiency determined in each plate for each amplicon, and the Cq value determined per sample, were used to calculate a starting amount of target DNA per sample (N0), expressed in arbitrary fluorescence units. As these fluorescent values depend on the size of the amplicon and are inevitably affected by the efficiency with which the DNA was extracted from each plant sample, they were normalized to the size of the amplicon, and to the N0 value of the plant gene amplicon. To confirm that N0 values can accurately estimate accumulations of the different target DNA, N0 values obtained from ten-fold dilutions (from $1.15 \times 10^{3}$ to $1.15 \mathrm{x}$ $10^{8}$ copies) of recombinant plasmid DNA containing the genome of TYLCV, CLCuGA, OLCBFA or CLCuGB. As observed on Suppl. Figure 1, N0 values derived from each dilution 
are proportional to the copy numbers. Thus, N0 values directly extracted from qPCR analyses are hereafter referred to as an estimation of the amount of virus or satellite molecules.

\subsection{Southern Blot analysis}

Approximately $5 \mu \mathrm{g}$ of total DNA extract per plant sample was fractionated by electrophoresis on $1 \%$ agarose gels containing TAE buffer. Three plants were tested for each treatment and each sampling date (32 and $150 \mathrm{dpi}$ ). After an alkaline denaturation, DNAs were transferred overnight on Hybond-N+ nylon membranes (GE Healthcare) by the capillary method described in the Hybond N+ membrane southern blot protocol (GE Healthcare), and subsequently UV cross-linked. Probes, consisting of full length linearized genome of CLCuGA or CLCuGB, were labelled with ${ }^{32} \mathrm{P}$ by random priming using the Prime-a-gene kit (Promega, France). Hybridization was performed overnight at $65^{\circ} \mathrm{C}$ using a standard protocol (Sambrook et al., 1989). The hybridization buffer was composed of $4 \times$ SSC, $2.5 \times$ Denhardt's solution, $1 \%$ SDS, $10 \mu \mathrm{g} / \mathrm{ml}$ of salmon sperm DNA, $1 \mathrm{M}$ Tris $\mathrm{pH} 8$, and $1 \mathrm{mM}$ EDTA and Dextran sulfate (10\%). Hybridization signals were detected by phosphorimaging using a Typhoon FLA 9000 imager (GE Healthcare).

\subsection{Insect transmission by the vector B. tabaci}

The efficiency of transmission of TYLCV-Mld, OLCBFA and CLCuGB was assessed according to the percentage of infected plants following inoculation with female whiteflies in three distinct experiments.

In experiment $\mathrm{A}$, whiteflies belonged to the genotype $\mathrm{Q} 2$ of the Mediterranean (MED) species of the B. tabaci complex. The population reared on cucumber was derived from individuals collected in Hyeres (France). Approximately 400 freshly emerged adults were given an acquisition access period (AAP) of $48 \mathrm{~h}$ on three individually caged 32 dpi tomato plants with the following combination: TYLCV-Mld, TYLCV-Mld/OLCBFA, or TYLCVMld/CLCuGB. At the end of the AAP, two females selected under a stereomicroscope were caged on 14-day-old tomato plants for a 5-day inoculation access period (IAP).

The same experimental conditions were used in transmission experiment $\mathrm{B}$ with TYLCV-Mld or TYLCV-Mld/CLCuGB infected source plants. B. tabaci individuals were of the genotype Q1 of Med species. The population was reared on cucumber, and derived from individuals collected in Angers (France). 
In a third experiment (C), tomato plants infected with TYLCV-Mld or TYLCV-Mld /CLCuGB were used as source plants at 32 and 150 dpi. AAP and IAP were the same as in experiments A and B except that three Q1 females were used per transmission.

At 32 dpi, test plants of TYLCV-Mld, and TYLCV-Mld/CLCuGB treatments which did not show typical symptoms induced by TYLCV-Mld or TYLCV-Mld/CLCuGB were tested by qPCR for the presence of virus and betasatellite. All the test plants of the TYLCVMld/OLCBFA treatment were tested by qPCR using specific primers (Suppl. Table 1).

\subsection{Statistical analysis}

All statistical analyses concerning virus and satellite accumulations were performed using R Studio software, version 3.0.3 (R_Development_Core_Team, 2010). At each sampling time point, ANOVA tests were used to compare accumulation values of virus and satellite between different groups of plants, and to compare different targets within treatments. Comparisons were performed after a $\log$ transformation of accumulation data. Transmission efficiencies were analyzed with a generalized linear model (GLM) and a hierarchical GLM model with a binomial distribution (JMP 13, SAS Institute Inc, Cary, North Carolina, USA).

\section{RESULTS}

\subsection{Impact of DNA satellites on symptoms and plant growth in TYLCV-Mld infected plants}

Tomato plants were agroinoculated with TYLCV-Mld, either alone (TM), or together with the betasatellite CLCuGB (TM/B), the alphasatellites CLCuGA (TM/CA) or OLCBFA (TM/OA), or with a combination of CLCuGB and each alphasatellite (TM/B/CA, TM/B/OA) (Table 1, experiment 1). As agroinoculation was not $100 \%$ successful, some of the inoculated plants were not infected, or at least not infected with all the components in the mixed inoculations. Only plants which were detected positive for all agroinoculated clones (qPCR at $18 \mathrm{dpi}$ ) were used for further analysis, including symptom observation, growth measurements and accumulations. Plants agroinoculated with an empty plasmid did not show any symptoms (Fig. 1 A). Plants infected with TYLCV-Mld showed typical symptoms of yellowing and leaf curling at 32 dpi (Fig. 1 B). These symptoms were not distinguishable from those of plants in which TYLCV-Mld was coinfected with alphasatellites (TM/CA, TM/OA, data not shown). However, all plants containing CLCuGB (TM/B, TM/B/CA, TM/B/OA) exhibited downward 
leaf curling, crumpling and distorsion of leaflets, and stunted plant growth (Fig.1 C). These symptoms were easily distinguishable from those induced by TYLCV-Mld alone.

The impact of virus and satellite on plant growth was estimated by measuring plant height at 32 dpi (Fig. 2). Plants of TM and TM/OA treatments have similar size with mockagroinoculated plants whereas other plants were smaller. All plants infected with TYLCVMld and the betasatellite irrespective of the satellite combination (TM/B, TM/B/CA and TM/B/OA) were smaller than TYLCV-Mld-infected plants.

\subsection{Accumulation dynamics of TYLCV-Mld and DNA satellites}

Accumulations of virus and satellites were estimated between 11 and 32 dpi (Table 1, Experiment 1). Accumulation levels increased between $11 \mathrm{dpi}$ and $18 \mathrm{dpi}$, and particularly those of satellites (Fig. 3 A, B, C and D). The maximum accumulation was detected at 18 dpi for TYLCV-Mld and generally at 18 or 25 dpi for CLCuGB and alphasatellites (Fig. 3). In some of the plants that were tested positive at $18 \mathrm{dpi}$ for all inoculated clones, satellite amounts were below the detection level at $11 \mathrm{dpi}$ : 28\% of the CLCuGA, (TM/CA and TM/B/CA), 35\% of the OLCBFA (TM/OA and TM/B/OA), and 10\% of the CLCuGB (TM/B, $\mathrm{TM} / \mathrm{B} / \mathrm{CA}$ and $\mathrm{TM} / \mathrm{B} / \mathrm{OA}$ ) plants On the contrary, almost all the plants that were tested positive for TYLCV-Mld-at $18 \mathrm{dpi}$ were already positive at $11 \mathrm{dpi}(98.5 \%)$.

TYLCV-Mld and satellites accumulations were compared to each other in each treatment and time points. The mean accumulation of TYLCV-Mld was higher than that of any satellite at 11 dpi irrespective of treatment (Fig. 4). However, it was significantly below that of CLCuGB in all treatments from $18 \mathrm{dpi}$, except in TM/B/OA treatment at $18 \mathrm{dpi}$. Interestingly, the dominance of accumulation of CLCuGB over that of TYLCV-Mld was due not only to a high accumulation level of CLCuGB per se, but also to the negative impact of CLCuGB on the accumulation of TYLCV-Mld. Indeed, from $18 \mathrm{dpi}$, the accumulation of TYLCV-Mld was significantly lower in the presence of CLCuGB (treatments TM/B, TM/B/CA or TM/B/OA) than in other treatments (Fig. 3 A). Alphasatellites did not modulate the negative impact of CLCuGB on TYLCV-Mld (TM/B/CA and TM/B/OA; Fig. 3 C, D).

Unlike betasatellite, accumulation levels of alphasatellites were often similar to, or lower than, those of TYLCV-Mld until $32 \mathrm{dpi}$ (Fig. 4), and, when it was higher, did not exceed twice the virus accumulation level. The only significant effect of alphasatellites on TYLCV-Mld was detected at $32 \mathrm{dpi}$ in the treatment TM/OA, where TYLCV-Mld accumulation was significantly lower than that in treatment TM (Fig.3 A). Each type of DNA satellite did not affect the accumulation level of other types (Fig.3 C, D), except at 25 and 
32 dpi for treatment TM/B/OA, where CLCuGB accumulation was significantly lower than that of treatment TM/B (Fig. 3 B).

\subsection{Maintenance of DNA satellites by TYLCV-Mld and TYLCV-IL until 150 dpi}

In view of the low accumulation of TYLCV-Mld in the presence of the betasatellite, at 32 dpi, the fate of this association was tested beyond this date with TYLCV-Mld and also TYLCV-IL the other TYLCV strain widespread in the Mediterranean area. To do this, tomato plants, agroinoculated with TYLCV-Mld or TYLCV-IL and CLCuGB (TM, TM/B TIL, TIL/B), were monitored at 18, 32 and 150 dpi (Experiments 2 and 3, Table 1). The maintenance of CLCuGA was also tested until 150 dpi in experiment 2. As specified above, only plants which were tested positive by qPCR at 18 dpi for all agroinoculated clones were used for qPCR analyses at 32 and 150 dpi. Typical leaf symptoms of yellowing and curling were observed on plants infected with TM, TM/CA or TIL at 32 dpi (Fig. 1 B, D) and 150 dpi (Fig. 1 G, I). The symptoms exhibited at 150 dpi by plants infected with the betasatellite (TM/B and TIL/B) were similar to those of the betasatellite-infected plants of the previous experiment (Fig. $1 \mathrm{H}$ and $\mathrm{J}$ ).

In experiment 2 and 3, as in experiment 1, the accumulation of CLCuGB at 18 and 32 dpi was higher than that of TYLCV-Mld and a deleterious effect on the accumulation of TYLCV-Mld was detected (Fig. 5, Suppl. Figure 2). At $150 \mathrm{dpi}$, accumulations of virus and betasatellite were not significantly different and were similar to the reduced accumulation of TYLCV-Mld at $32 \mathrm{dpi}$ in the presence of the betasatellite. The deleterious effect of the betasatellite was not detected at 150 dpi where TYLCV-Mld accumulated at similar level in TM and TM/B treatment (Fig. 5, Suppl. Figure 2). CLCuGA was maintained until 150 dpi at higher level than the virus (Suppl. Figure 2).

The results obtained with TYLCV-IL stand in contrast to those obtained with TYLCVMld. Indeed, TYLCV-IL accumulation was not reduced by the betasatellite (Fig. 5). It was even increased in TIL/B treatment at 32 dpi. CLCuGB accumulated at similar level with each virus strains, except at $150 \mathrm{dpi}$, where it was higher in TIL/B- than in TM/B-infected plants.

\subsection{Generation of defective genomes of satellites}

The genomic composition of CLCuGB and CLCuGA DNAs were analyzed by Southern blot analysis (3 plants) and PCR (2-4 plants) in plants (Experiment 2), sampled at 32 and 150 dpi in the TM/B and TM/CA treatments. Southern blot analyses revealed the presence of fulllength genomes at 32 and 150 dpi but also smaller DNA bands in 150 dpi samples (Suppl. 
Fig. 3A). PCR analysis were consistent with the Southern blot analysis with products of the expected full length genome size in 32 dpi samples and mainly smaller size products in 120 and 150 dpi samples: about 1000 bp for CLCuGB and 500 to 750 bp for CLCuGA. At 32 dpi, small sized PCR products were detected with TM/CA samples (about 700 bp) but not with TM/B samples (Suppl. Fig. 3B). The major amplicons obtained from two different plants of TM/B and TM/CA were gel purified and sequenced. Sequences obtained from 32 dpi TM/B and TM/A samples corresponded to that of the full length CLCuGB and CLCuGA DNA. Sequences of major amplicons obtained from $150 \mathrm{dpi}$ TM/B plant samples consisted of a genome of $\mathrm{CLCuGB}$ deleted in the $\beta \mathrm{Cl}$ gene (ORF nts 195-548) between nucleotide positions 203 and 633 (Suppl. Fig. 3C). The two sequences of alphasatellite amplicons of $\sim 700$ bp exhibited a deletion in the alpha-Rep gene (ORF nts 65-1010) between positions 362 and 1064 and an insertion of a TYLCV-Mld sequence (Suppl. Fig. 3C). One defective CLCuGA was of $780 \mathrm{nts}$ and the insertion was a portion of the $C 3$ virus gene (nts 1285-1067). The other CLCuGA was of $690 \mathrm{nts}$ and the insertion was a portion of the $C 1$ virus gene (nts 2548-2444) (Suppl. Fig. 3C).

\subsection{Impact of CLCUGB on a resistant cultivar bearing the Ty-1 resistance gene}

As CLCuGB dramatically exacerbates symptoms of TYLCV strains in susceptible tomato plants (Fig. 1), it was thought that it may break the resistance associated with $T y-1$ gene widely used in the Mediterranean area. Tomato plants of the resistant cultivar Pristyla, and a nearly isogenic susceptible cultivar, were inoculated with TYLCV-Mld (Experiment 4) or TYLCV-IL clones (Experiment 5) and with the CLCuGB clone. Symptoms were recorded and accumulations of virus and satellite were estimated as before.

Resistant plants infected with TYLCV-IL or TYLCV-Mld did not show any symptoms (Fig. 1 L, N). However, when they were co-infected with CLCuGB, mild mosaic and leaf curling was observed at 18 and $32 \mathrm{dpi}$, but without stunting (Fig. $1 \mathrm{M}, \mathrm{O}$ ); symptoms became milder after this time point, and had disappeared by $150 \mathrm{dpi}$.

As observed previously, TYLCV-Mild accumulation was negatively affected by the betasatellite in the susceptible cultivar at 18 and 32 dpi (Fig.6), and CLCuGB accumulated at higher level than that of the virus at $32 \mathrm{dpi}$. A similar trend was observed in the resistant cultivar although at a lower accumulation level. As observed in the susceptible Monalbo cultivar, TYLCV-IL accumulation was generally similar between TIL and TIL/B treatments in the susceptible cultivar (Fig.7). In the resistant cultivar, it was significantly increased in the presence of CLCuGB at 18 and 32 dpi (10 and 5 times, respectively). 
Although both helper viruses accumulated 20-40 times less in Ty-1-resistant plants than in susceptible plants in both treatments (Figs. 6 and 7), accumulation of CLCuGB was much less affected in the presence of TYLCV-IL than in the presence of TYLCV-Mld: at 32 dpi; for example, 8 times versus 2.5 times less, respectively.

\subsection{Vector transmission of TYLCV-Mld and satellites}

As CLCuGB and OLCBFA were shown to affect TYLCV-Mld accumulation at $32 \mathrm{dpi}$ (Fig. 3 A), they may affect the efficiency of the virus transmission by its whitefly vector $B$. tabaci. To test this hypothesis, three independent transmission tests (A, B, C) were performed with TYLCV-Mld-infected source plants, coinfected or not with a satellite (Suppl Table 2). Three independent source plants were used per treatment: TYLCV-Mld (TM) or TYLCV-Mld and CLCuGB (TM/B) or TYLCV-Mld and OLCBFA (TM/OA).

Transmission efficiency of TYLCV-Mld and CLCuGB was estimated at $32 \mathrm{dpi}$ in three transmission tests (A, B, C). Virus and satellite accumulations were estimated by qPCR in each of the source plants the day before the beginning of the AAP. As in previous experiments, accumulation of TYLCV-Mld was higher in TM than in TM/B treatments, and the betasatellite accumulated more than TYLCV-Mld in all plants (Suppl. Fig 4). CLCuGB was transmitted to $50 \%(3 / 6), 100 \%$ (6/6), and 64\% (18/28) of TYLCV-Mld-infected test plants in experiments A, B and C, respectively (Suppl. table 2). All the test plants that were positive for the detection of CLCuGB showed severe symptoms similar to those previously observed on $32 \mathrm{dpi}$ TM/B infected plants. Mean transmission efficiency of TYLCV-Mld was higher from TM-infected plants than from TM/B plants in experiment B (13.1\% versus $5.9 \%$; Fisher's exact test; $p$-value $=0.0342$, Suppl. Table 2$)$ and in experiment A (21.9 versus $10.5 \%)$ but not in experiment C (19.8 versus 24.6\%). However differences were not significant between the two treatments in experiments $\mathrm{A}$ and $\mathrm{C}$. The significant difference detected in experiment B may be associated with the higher ratio of mean accumulation of TYLCV-Mld between TM and TM/B treatments -5 in experiment $\mathrm{B}$ instead of 2 in experiments $\mathrm{A}$ and $\mathrm{C}$ - and because more tests were performed in experiment B for TM and TM/B (120 and 134 respectively, compared with 60 for each treatment in experiment $A$, and 60 and 111 in experiment $\mathrm{C}$ ).

The decrease of accumulation levels of TYLCV-Mld and CLCuGB in tomato plants at 150 dpi (Figs. 5 and Suppl. Fig. 2) may have a negative impact on the transmission efficiency of CLCuGB by B. tabaci. The transmission efficiency of CLCuGB was estimated from three 150-day-old TM/B infected tomato plants in experiment C. Accumulation levels of TYLCV- 
Mld and CLCuGB were similar in source plants at $150 \mathrm{dpi}$, and the mean amount of CLCuGB was lower than that at 32 dpi (Suppl. Fig 4). CLCuGB from the 150 dpi plants was transmitted to $30 \%$ (4/13) of TYLCV-Mld-infected plants (Suppl. Table 2). All the test plants that were positive for the detection of CLCuGB showed severe symptoms typical of the presence of the betasatellite. This result indicates that the decrease of TYLCV-Mld and CLCuGB amounts at 150 dpi did not prevent the transmission of the betasatellite.

The transmission test with OLCBFA was performed with 32 dpi-infected plants (Experiment A). It was transmitted to $75 \%$ (6/8) of TYLCV-Mld infected plants, and the difference of transmission efficiency of TYLCV-Mld between TM- and TM/OA treatments was not significant (Suppl. Fig.4).

\section{DISCUSSION}

The seriousness of the "satellite risk" to TYLCV infected tomato was assessed by testing experimentally two criteria associated with their maintenance: their accumulation level with respect to that of the helper virus, and their efficiency to be transmitted by their natural whitefly vector at an early and later stage of infection. To increase the relevance of the study, accumulation studies were performed with susceptible and $T y-1$ resistant cultivars because virtually all TYLCV-resistant cultivars in the Mediterranean have the Ty- 1 resistance gene. Unlike previous studies in which accumulations of virus or satellite were compared only between treatments, the conceptual and technical originality of the present study was, in addition to treatment comparisons, to compare the targeted molecules to each other within plants. As the determination of an absolute copy number was not the major objective of the study, a direct comparison of normalized fluorescence amounts was favored for its expected higher accuracy (Suppl. Figure 1). Indeed, it bypasses errors generated by the transformation of fluorescence data to absolute copy number with standard curves.

Results obtained by comparing satellite accumulation with virus accumulation are consistent with an efficient maintenance of satellite molecules in tomato plants. From one month after inoculation, accumulation levels of satellites in systemically infected leaves were at least as high as those of helper viruses, which indicate that satellites replicated and moved efficiently within plants. From these accumulation results, it is expected that satellite molecules will be efficiently transmitted from plant to plant, a step which is essential for their survival. As DNA satellites are encapsidated in the viral capsid protein, the unique determinant of transmission specificity by insect vectors (Azzam et al., 1994; Briddon et al., 
1990), it can be assumed that the transmission efficiency of encapsidated molecules (viral or satellite molecules) is mainly determined by their frequency in plant sap. Thus, as the accumulation level of satellites at one month post infection is mostly higher than that of the virus, and in the case of betasatellite, up to 10 times higher, satellites are expected to be inoculated by the vector into new plants as efficiently as the helper virus. This prediction was confirmed with the transmission tests.

The detection of a substantial fraction of defective satellite molecules at 150 dpi raises the question of what is actually maintained and transmitted from plant to plants. The analysis of defective molecules of alphasatellites and betasatellites by sequencing revealed that they exhibited a complete or partial deletion of their gene which is fully consistent with previous reports (Briddon et al., 2001; Saunders et al., 2000; Saunders and Stanley, 1999; Stanley et al., 1997). This result is directly connected with the issue of the "betasatellite risk" because the negative impact induced to plants by this satellite was shown to be associated to a functional $\beta C 1$ gene (Cui et al., 2004; Qian and Zhou, 2004; Saunders et al., 2004; Yang et al., 2011a). However, although Southern blot analysis indicate that defective betasatellite molecules were more frequent than full length molecules in 150 dpi plants, the qPCR results show that potentially full length betasatellites, i.e. those amplified with the $\beta C 1$ targeted primers, accumulated at least as much as virus genomes. In any case, at $150 \mathrm{dpi}$, the full length satellite genomes were frequent enough to induce severe symptoms on those plants and on the test plants that were inoculated from them. Similarly, alphasatellites defective molecules are probably transreplicated by full length genomes detected with the alpha-Rep targeted primers.

Analysis of satellite accumulation reveals unexpected features of these molecules. Indeed, although betasatellites are not autonomous for their replication, their accumulation level was higher than that of alphasatellites and that of helper viruses (TYLCV-IL, TYLCVMld). This result uncovers a novel facet of the parasitic potential of betasatellites. It was already reported that they exhibited a tremendously high flexibility to be assisted by a large range of helper viruses (Kon et al., 2009; Patil and Fauquet, 2010; Saunders et al., 2008); it is noteworthy that although TYLCV-IL and TYLCV-Mld encode different Rep proteins due to the recombinant nature of TYLCV-IL in the Rep gene (Navas-Castillo et al., 2000), similar accumulation levels were obtained for CLCuGB, which further confirm the flexibility of betasatellites for replication. Here, in addition to flexibility of replication, we show that its replication is highly efficient, which reflects that the replication complex formed by the viral Rep is efficiently hijacked for betasatellites' benefit. This result is all the more remarkable 
given the fact that CLCuGB is not known to have co-evolved with TYLCV and does not contain the viral iteron sequences essential for replication of helper viruses (Fontes et al., 1994; Laufs et al., 1995). Moreover, the difference of size between virus and betasatellite molecules may also contribute to a higher replication rate of satellite genomes as previously proposed for defective molecules(Stenger et al., 1992); this hypothesis may also hold for alphasatellites.

Another result that account for the "betasatellite risk" is that it partially breaks the resistance induced by the $T y-1$ gene that is present in virtually all TYLCV resistant plants used in the Mediterranean Basin. The unusual symptom expression observed in resistant plants could not be easily explained by an increased virus accumulation in the presence of the betasatellite. Indeed, this would only hold for TYLCV-IL, but not for TYLCV-Mld for which accumulation was reduced in the presence of the betasatellite. Therefore, it is thought that these symptoms are due to the $\beta C 1$ protein which was shown to induce symptoms when expressed in transgenic plants (Cui et al., 2004; Saunders et al., 2004). However, if so, the attenuation of symptoms after 32 dpi cannot be easily explained because the betasatellite accumulation did not decrease. It is possible that the general resistance of plant increases over time. The betasatellite risk might be tolerable if its negative impact remained limited to a slight increase of TYLCV-IL accumulation and symptoms exhibition up to $32 \mathrm{dpi}$. However as the Ty-1 gene does only reduce and not block virus and satellite replication, a more competitive virus/satellite complex may be positively selected over time by resistant plants as recently reported for the invasive TYLCV-IS76 recombinant (Belabess et al., 2015; Belabess et al., 2016). For example, it cannot be excluded that a complex in which, the betasatellite would increase TYLCV-IL accumulation beyond 32 dpi could be selected. The protein $\beta C 1$ which was shown to be involved in suppression of enhanced TGS (Amin et al., 2011; Cui et al., 2005; Yang et al., 2011b) may temporally counteract the effect of $T y-1$ gene which encodes a RNA-dependent RNA polymerase (Verlaan et al., 2013) associated with increasing cytosine methylation of the begomovirus genome, suggestive of TGS (Butterbach et al., 2014). A similar antagonistic effect may exist regarding virus movement in plant, facilitated by $\beta C 1$ (Patil and Fauquet, 2010; Saeed et al., 2007) but impeded by the $T y-1$ gene (Michelson, 1994).

Although TYLCV-Mld and TYLCV-IL were efficient for the maintenance of the betasatellite, both TYLCV strains interact differently with CLCuGB. The negative impact of CLCuGB on TYLCV-Mld accumulation goes against the general view that betasatellites generally increase helper virus accumulation (Jyothsna et al., 2013; Kon and Gilbertson, 
2012; Kon et al., 2009; Kumar et al., 2015) or at least do not affect it(Zhang et al., 2009). However, this negative impact seems consistent with the Southern-blot results obtained previously with tomato plants infected with TYLCV-Mld or TYLCV-Mld/AYVB [(Ueda et al., 2012) in Fig. 3]. Interestingly, the negative impact on accumulation was not observed at $150 \mathrm{dpi}$, when the amount of functional CLCuGB molecules decreased in TM/B treatment (Figs 5, Suppl. Fig. 2). These results suggest that it is the complete genome of CLCuGB, and possibly a functional $\beta C 1$ gene, which affects TYLCV-Mld accumulation. TYLCV-IL accumulation was not affected by CLCuGB in two independent experiments performed with different susceptible cultivars; this result stands in contrast with the increased accumulation of TYLCV-IL observed with a CLCuGB isolate from Mali that exhibited only $4 \%$ nucleotide divergence with our clone (Kon et al., 2009). Taken together, the contrasting results indicate that the outcomes of TYLCV/betasatellite interactions may depend on slight molecular differences or on experimental conditions.

Considering the efficient maintenance of CLCuGB by TYLCV-Mld and TYLCV-IL in tomato plants, their efficient transmission, and the increased accumulation of TYLCV-IL in Ty-1 resistant plants, the "betasatellite risk" in the Mediterranean tomato production should not be neglected. However, what is presently unknown and cannot be easily monitored in controlled conditions is the effect of the environment on the maintenance of a begomovirus/satellite complex in which, the satellite is not providing an obvious fitness increase to the helper virus, as in the case of TYLCV. In Asia and Africa where some association are beneficial for the virus (for example Cotton leaf curl virus, Tomato yellow leaf curl China virus), a pool of betasatellites is maintained in the agrosystem, and can be assisted by other begomovirus species in an opportunistic manner. This may be the case for ToLCNDV in India (Jyothsna et al., 2013). The maintenance of betasatellites in Western Mediterranean countries, where betasatellites have not been reported, is obviously more challenging. ToLCNDV which was accidently introduced into several countries in Western Mediterranean may play a role in their maintenance because it was reported to obtain a benefit from betasatellites for transmission (Sivalingam and Varma, 2012). In Eastern Mediterranean region, the agrosystem is apparently more conducive to the maintenance of betasatellites. Indeed, CLCuGB, the betasatellite detected in association with TYLCV in tomato plants in Jordan, was detected in Sinapis arvensis a wide spread weed in which four begomovirus species were detected as well. Surprisingly, in China and Japan where both TYLCV and betasatellite are present, TYLCV/betasatellite associations have not been reported so far (Kato et al., 1998; Mugiira et al., 2008; Ueda et al., 2008; Wu et al., 2006). Further surveys are 
needed to detect and monitor the frequency of begomovirus/betasatellite in countries where both TYLCV and betasatellites have been detected like Jordan, Egypt, Japan and China. Such surveys are expected to conveniently complete the estimation of the "betasatellite risk" monitored with TYLCV in experimental conditions.

\section{Conflict of Interest}

The authors declare that they have no conflict of interest.

\section{Acknowledgments}

Déborah Conflon is a PhD student from Montpellier SupAgro, France. She received a grant from CIRAD (http://www.cirad.fr/) and ANSES (https://www.anses.fr). The authors are grateful to Jean-Luc Macia and Sophie Le Blaye for their excellent technical assistance in growing and sampling the plants. Gautier Semences (Eyrargues, France) supported the project and supplied the tomato seeds of "Monalbo", "Pristyla" and its nearly isogenic susceptible cultivar. All experiments were done in P3 containment growth chambers in which CIRAD was authorized to conduct experiments with begomoviruses and their whitefly vector Bemisia tabaci, by the prefectural order 2012114-0003 signed at Montpellier the $23^{\text {rd }}$ of April 2012 


\section{REFERENCES}

Abbas, Q., Amin, I., Mansoor, S., Shafiq, M., Wassenegger, M., Briddon, R.W., 2017. The Rep proteins encoded by alphasatellites restore expression of a transcriptionally silenced green fluorescent protein transgene in Nicotiana benthamiana. Virus Disease.

Abdel-Salam, A.M., Ur-Rehman, M.M., Salama M., E.-S., 2017. Genetic diversity, natural host range and molecular pathogenesis of begomovirus-associated betasatellites in Egypt. International Journal of Virology 13, 29-42.

Amin, I., Hussain, K., Akbergenov, R., Yadav, J.S., Qazi, J., Mansoor, S., Hohn, T., Fauquet, C.M., Briddon, R.W., 2011. Suppressors of RNA silencing encoded by the components of the Cotton leaf curl begomovirus-betasatellite complex. Molecular Plant-Microbe Interactions 24, 973-983.

Anfoka, G., Ahmad, F.H., Altaleb, M., Al Shhab, M., 2014. Detection of satellite DNA beta in tomato plants with Tomato yellow leaf curl disease in Jordan. Plant Disease 98, 1017.

Azzam, O., Frazer, J., de la Rosa, D., Beaver, J.S., Ahlquist, P., Maxwell, D.P., 1994. Whitefly transmission and efficient ssDNA accumulation of bean golden mosaic geminivirus require functional coat protein. Virology 204, 289-296.

Belabess, Z., Dallot, S., El-Montaser, S., Granier, M., Majde, M., Tahiri, A., Blenzar, A., Urbino, C., Peterschmitt, M., 2015. Monitoring the dynamics of emergence of a noncanonical recombinant of Tomato yellow leaf curl virus and displacement of its parental viruses in tomato. Virology 486, 291-306.

Belabess, Z., Peterschmitt, M., Granier, M., Tahiri, A., Blenzar, A., Urbino, C., 2016. The non-canonical tomato yellow leaf curl virus recombinant that displaced its parental viruses in southern Morocco exhibits a high selective advantage in experimental conditions. Journal of General Virology 97, 3433-3445.

Briddon, R.W., Bull, S.E., Amin, I., Mansoor, S., Bedford, I.D., Rishi, N., Siwatch, S.S., Zafar, Y., Abdel-Salam, A.M., Markham, P.G., 2004. Diversity of DNA 1: a satellite-like molecule associated with monopartite begomovirus-DNA $\beta$ complexes. Virology $324,462-$ 474.

Briddon, R.W., Bull, S.E., Mansoor, S., Amin, I., Markham, P.G., 2002. Universal primers for the PCR-mediated amplification of DNA $\beta$. Mol Biotechnol 20, 315-318.

Briddon, R.W., Mansoor, S., Bedford, I.D., Pinner, M.S., Saunders, K., Stanley, J., 2001. Identification of DNA components required for induction of cotton leaf curl disease. Virology. 285.

Briddon, R.W., Pinner, M.S., Stanley, J., Markham, P.G., 1990. Geminivirus coat protein gene replacement alters insect specificity. Virology 177, 85-94.

Briddon, R.W., Stanley, J., 2006. Subviral agents associated with plant single-stranded DNA viruses. Virology 344, 198-210.

Butterbach, P., Verlaan, M.G., Dullemans, A., Lohuis, D., Visser, R.G.F., Bai, Y., Kormelink, R., 2014. Tomato yellow leaf curl virus resistance by Ty-1 involves increased cytosine methylation of viral genomes and is compromised by cucumber mosaic virus infection. Proceedings of the National Academy of Sciences USA 111, 12942-12947.

Cui, X.F., Li, G.X., Wang, D.W., Hu, D.W., Zhou, X.P., 2005. A begomovirus DNA betaencoded protein binds DNA, functions as a suppressor of RNA silencing, and targets the cell nucleus. Journal of Virology 79, 10764-10775.

Cui, X.F., Tao, X.R., Xie, Y., Fauquet, C.M., Zhou, X.P., 2004. A DNA beta associated with Tomato Yellow Leaf Curl China Virus is required for symptom induction. Journal of Virology 78, 13966-13974. 
Delatte, H., Holota, H., Naze, F., Peterschmitt, M., Reynaud, B., Lett, J.M., 2005. The presence of both recombinant and nonrecombinant strains of Tomato yellow leaf curl virus on tomato in Reunion Island. Plant Pathology 54, 262.

Dry, I.B., Rigden, J.E., Krake, L.R., Mullineaux, P.M., Rezaian, M.A., 1993. Nucleotide sequence and genome organization of tomato leaf curl geminivirus. Journal of General Virology 74, 147-151.

Fontes, E.P., Eagle, P.A., Sipe, P.S., Luckow, V.A., Hanley-Bowdoin, L., 1994. Interaction between a geminivirus replication protein and origin DNA is essential for viral replication. The Journal of Biological Chemistery 269, 8459-8465.

Heyraud-Nitschke, F., Schumacher, S., Laufs, J., Schaefer, S., Schell, J., Gronenborn, B., 1995. Determination of the origin cleavage and joining domain of geminivirus Rep proteins. Nucleic Acids Res 23, 910-916.

Idris, A.M., Shahid, M.S., Briddon, R.W., Khan, A.J., Zhu, J.K., Brown, J.K., 2011. An unusual alphasatellite associated with monopartite begomoviruses attenuates symptoms and reduces betasatellite accumulation. Journal of General Virology 92, 706-717.

Ito, T., Kimbara, J., Sharma, P., Ikegami, M., 2009. Interaction of Tomato yellow leaf curl virus with diverse betasatellites enhances symptom severity. Archives of Virology 154, 1233-1239.

Jyothsna, P., Haq, Q.M.I., Singh, P., Sumiya, K.V., Praveen, S., Rawat, R., Briddon, R., Malathi, V.G., 2013. Infection of tomato leaf curl New Delhi virus (ToLCNDV), a bipartite begomovirus with betasatellites, results in enhanced level of helper virus components and antagonistic interaction between DNA B and betasatellites. Appl Microbiol Biotechnol 97, $5457-5471$.

Kato, K., Onuki, M., Fuji, S., Hanada, K., 1998. The First Occurrence of Tomato Yellow Leaf Curl Virus in Tomato (Lycopersicon esculentum Mill.) in Japan. 64, 552-559.

Khan, A.J., Idris, A.M., Al-Saady, N.A., Al-Mahruki, M.S., Al-Subhi, A.M., Brown, J.K., 2008. A divergent isolate of tomato yellow leaf curl virus from Oman with an associated DNA beta satellite: an evolutionary link between Asian and the Middle Eastern virussatellite complexes. Virus Genes 36, 169-176.

Kheyr-Pour, A., Bendahmane, M., Matzeit, V., Accotto, G.P., Crespi, S., Gronenborn, B., 1991. Tomato yellow leaf curl virus from Sardinia is a whitefly-transmitted monopartite geminivirus. Nucleic Acids Research 19, 6763-6769.

Kon, T., Gilbertson, R.L., 2012. Two genetically related begomoviruses causing tomato leaf curl disease in Togo and Nigeria differ in virulence and host range but do not require a betasatellite for induction of disease symptoms. Archives of Virology 157, 107-120.

Kon, T., Rojas, M.R., Abdourhamane, I.K., Gilbertson, R.L., 2009. Roles and interactions of begomoviruses and satellite DNAs associated with okra leaf curl disease in Mali, West Africa. Journal of General Virology 90, 1001-1013.

Kumar, J., Gunapati, S., Alok, A., Lalit, A., Gadre, R., Sharma, N., Roy, J., Singh, S., 2015. Cotton leaf curl Burewala virus with intact or mutant transcriptional activator proteins: complexity of cotton leaf curl disease. Archives of Virology 160, 1219-1228.

Kumar, J., Gunapati, S., Singh, S., Kumar, A., Lalit, A., Sharma, N., Puranik, R., Tuli, R., 2013. A new betasatellite associated with cotton leaf curl Burewala virus infecting tomato in India: influence on symptoms and viral accumulation. Archives of Virology 158, 13491353.

Kumar, J., Kumar, J., Singh, S.P., Tuli, R., 2014. Association of satellites with a mastrevirus in natural infection: complexity of Wheat dwarf India virus disease. Journal of Virology 88, 7093-7104. 
Laufs, J., Traut, W., Heyraud, F., Matzeit, V., Rogers, S.G., Schell, J., Gronenborn, B., 1995. In vitro cleavage and joining at the viral origin of replication by the replication initiator protein of tomato yellow leaf curl virus. Proc Natl Acad Sci USA 92, 3879-3883.

Lefeuvre, P., Martin, D.P., Harkins, G., Lemey, P., Gray, A.J.A., Meredith, S., Lakay, F., Monjane, A., Lett, J.-M., Varsani, A., Heydarnejad, J., 2010. The spread of Tomato yellow leaf curl virus from the Middle East to the world. PLoS Pathogens 6, e1001164.

Mansoor, S., Khan, S.H., Bashir, A., Saeed, M., Zafar, Y., Malik, K.A., Briddon, R., Stanley, J., Markham, P.G., 1999. Identification of a novel circular single-stranded DNA associated with cotton leaf curl disease in Pakistan. Virology 259, 190-199.

Michelson, I., Zamir, D. and Czosnek, H., 1994. Accumulation and translocation of tomato yellow leaf curl virus (TYLCV) in a Lycopersicon esculentum breeding line containing the L. chilense TYLCV tolerance gene TY-1. Phytopathology 84, 928-933.

Moriones, E., Navas-Castillo, J., 2000. Tomato yellow leaf curl virus, an emerging virus complex causing epidemics worldwide. Virus Research 71, 123-134.

Mugiira, R.B., Liu, S.S., Zhou, X., 2008. Tomato yellow leaf curl virus and Tomato leaf curl Taiwan virus Invade South-east Coast of China. Journal of Phytopathology 156, 217-221.

Navas-Castillo, J., Sanchez-Campos, S., Noris, E., Louro, D., Accotto, G.P., Moriones, E., 2000. Natural recombination between Tomato yellow leaf curl virus-Is and Tomato leaf curl virus. Journal of General Virology 81, 2797-2801.

Navot, N., Pichersky, E., Zeidan, M., Zamir, D., Czosnek, H., 1991. Tomato yellow leaf curl virus: A whitefly-transmitted geminivirus with a single genomic component. Virology 185, $151-161$.

Nawaz-ul-Rehman, M.S., Nahid, N., Mansoor, S., Briddon, R.W., Fauquet, C.M., 2010. Posttranscriptional gene silencing suppressor activity of two non-pathogenic alphasatellites associated with a begomovirus. Virology 405, 300-308.

Patil, B.L., Fauquet, C.M., 2010. Differential interaction between cassava mosaic geminiviruses and geminivirus satellites. Journal of General Virology 91, 1871-1882.

Pfaffl, M.W., 2001. A new mathematical model for relative quantification in real-time RTPCR. Nucleic Acids Research 29 (9), e45.

Qian, Y.J., Zhou, X.P., 2004. Pathogenicity and stability of a truncated DNA beta associated with Tomato yellow leaf curl China virus. Virus Research 109, 159-163.

R Development Core Team, 2010. R: A language and environment for statistical computing. R Foundation for Statistical Computing, Vienna.

Ranjan, P., Singh, A., Kumar, R.V., Basu, S., Chakraborty, S., 2014. Host-specific adaptation of diverse betasatellites associated with distinct Indian tomato-infecting begomoviruses. Virus Genes 48, 334-342.

Ruijter, J.M., Ramakers, C., Hoogaars, W.M.H., Karlen, Y., Bakker, O., van den Hoff, M.J.B., Moorman, A.F.M., 2009. Amplification efficiency: linking baseline and bias in the analysis of quantitative PCR data. Nucleic Acids Research 37 (6) e45.

Saeed, M., Zafar, Y., Randles, J.W., Rezaian, M.A., 2007. A monopartite begomovirusassociated DNA beta satellite substitutes for the DNA B of a bipartite begomovirus to permit systemic infection. Journal of General Virology 88, 2881-2889.

Sambrook, J., Fritsh, E.F., Maniatis, T., 1989. Molecular cloning: A laboratory manual. Cold spring Harbor Laboratory Press, Cold Spring Harbor, NY.

Saunders, K., Bedford, I.D., Briddon, R.W., Markham, P.G., Wong, S.M., Stanley, J., 2000. A unique virus complex causes Ageratum yellow vein disease. Proceedings of the National Academy of Sciences USA 97, 6890-6895.

Saunders, K., Bedford, I.D., Stanley, J., 2002. Adaptation from whitefly to leafhopper transmission of an autonomously replicating nanovirus-like DNA component associated with ageratum yellow vein disease. Journal of General Virology 83, 907-913. 
Saunders, K., Briddon, R.W., Stanley, J., 2008. Replication promiscuity of DNA-beta satellites associated with monopartite begomoviruses; deletion mutagenesis of the Ageratum yellow vein virus DNA-beta satellite localizes sequences involved in replication. Journal of General Virology 89, 3165-3172.

Saunders, K., Norman, A., Gucciardo, S., Stanley, J., 2004. The DNA $\beta$ satellite component associated with ageratum yellow vein disease encodes an essential pathogenicity protein $(\beta C 1)$. Virology 324, 37-47.

Saunders, K., Stanley, J., 1999. A nanovirus-like DNA component associated with yellow vein disease of Ageratum conyzoides: evidence for interfamilial recombination between plant DNA viruses. Virology 264, 142-152.

Shahid, M.S., Ikegami, M., Briddon, R.W., Natsuaki, K.T., 2015. Characterization of Tomato yellow leaf curl virus and associated alphasatellite infecting Cucurbita maxima in Japan. Journal of General Plant Pathology 81, 92-95.

Shahid, M.S., Ikegami, M., Waheed, A., Briddon, R.W., Natsuaki, K.T., 2014. Association of an alphasatellite with Tomato yellow leaf curl virus and ageratum yellow vein virus in Japan is suggestive of a recent introduction. Viruses 6, 189-200.

Sivalingam, P.N., Varma, A., 2012. Role of betasatellite in the pathogenesis of a bipartite begomovirus affecting tomato in India. Archives of Virology 157, 1081-1092.

Sohrab, S.S., Yasir, M., El-Kafrawy, S.A., 2017. Begomovirus infection on Cucumber in Saudi Arabia. Plant Omics 10, 7-14.

Stanley, J., Saunders, K., Pinner, M.S., Man Wong, S., 1997. Novel defective interfering DNAs associated with ageratum yellow vein geminivirus infection of Ageratum conyzoides. Virology 239, 87-96.

Stenger, D.C., Stevenson, M.C., Hormuzdi, S.G., Bisaro, D.M., 1992. A number of subgenomic DNAs are produced following agroinoculation of plants with beet curly top virus. Journal of Virology 73, 237-242.

Tiendrébéogo, F., Lefeuvre, P., Hoareau, M., Villemot, J., Konate, G., Traoré, A.S., 2010. Molecular diversity of Cotton leaf curl Gezira virus isolates and their satellite DNAs associated with okra leaf curl disease in Burkina Faso. Virology Journal 7: 48

Tiwari, N., Padmalatha, K.V., Singh, V.B., Haq, Q.M.I., Malathi, V.G., 2010. Tomato leaf curl Bangalore virus (ToLCBV): infectivity and enhanced pathogenicity with diverse betasatellites. Archives of Virology 155, 1343-1347.

Ueda, S., Onuki, M., Hanada, K., Takanami, Y., 2008. Unique grouping of the Far East Asian begomovirus complex based on sequence analyses of the DNA-A genome and associated DNA $\beta$ satellite molecules isolated from tomato, honeysuckle and Eupatorium plants in Japan. Archives of Virology 153, 417-426.

Ueda, S., Onuki, M., Yamashita, M., Yamato, Y., 2012. Pathogenicity and insect transmission of a begomovirus complex between Tomato yellow leaf curl virus and Ageratum yellow vein betasatellite. Virus Genes 44, 338-344.

Urbino, C., Gutierrez, S., Antolik, A., Bouazza, N., Doumayrou, J., Granier, M., Martin, D.P., Peterschmitt, M., 2013. Within-host dynamics of the emergence of tomato yellow leaf curl virus recombinants. Plos One 8, e58375.

Verlaan, M.G., Hutton, S.F., Ibrahem, R.M., Kormelink, R., Visser, R.G.F., Scott, J.W., Edwards, J.D., Bai, Y., 2013. The Tomato yellow leaf curl virus resistance genes Ty-1 and Ty-3 are allelic and code for DFDGD-class RNA-Dependent RNA polymerases. PLoS Genetics 9, e1003399.

Wu, J., Dai, F., Zhou, X., 2006. First report of Tomato yellow leaf curl virus in China. Plant Disease 90, 1359-1359.

Wu, J., Zulfiqar, A., Huang, C., 2011. Infectivity of Euphorbia leaf curl virus and interaction with Tomato yellow leaf curl China betasatellite. Archives of Virology 156, 517-521. 
Wu, P.J., Zhou, X.P., 2005. Interaction between a nanovirus-like component and the Tobacco curly shoot virus/satellite complex. Acta Biochimica Et Biophysica Sinica 37, 25-31.

Xie, Y., Wu, P., Liu, P., Gong, H., Zhou, X., 2010. Characterization of alphasatellites associated with monopartite begomovirus/betasatellite complexes in Yunnan, China. Virology Journal 7, 178.

Yang, X., Guo, W., Ma, X., An, Q., Zhou, X., 2011a. Molecular characterization of Tomato leaf curl China virus infecting tomato plants in China, and functional analyses of its associated betasatellite. Applied and Environmental Microbiology 77, 3092-3101.

Yang, X., Xie, Y., Raja, P., Li, S., Wolf, J.N., Shen, Q., Bisaro, D.M., Zhou, X., 2011b. Suppression of methylation-mediated transcriptional gene silencing by betaC1-SAHH protein interaction during geminivirus-betasatellite infection. PLoS pathogens 7, e1002329.

Zerbini, F.M., Briddon, R.W., Idris, A., Martin, D.P., Moriones, E., Navas-Castillo, J., Rivera-Bustamante, R., Roumagnac, P., Varsani, A., Consortium, I.R., 2017. ICTV Virus Taxonomy Profile: Geminiviridae. Journal of General Virology 98, 131-133.

Zhang, H., Gong, H., Zhou, X., 2009. Molecular characterization and pathogenicity of tomato yellow leaf curl virus in China. Virus Genes 39, 249-255.

Zhou, X., 2013. Advances in understanding begomovirus satellites. Annual Review of Phytopathology 51, 357-381. 


\section{Figure captions}

Figure 1: Leaf symptoms on susceptible and resistant tomato plants infected with TYLCVMld or TYLCV-IL, either alone or co-infected with CLCuGB.

A-E, susceptible plants (cv. Monalbo) at 32 days post-inoculation (dpi). A: healthy plant, B: TYLCV-Mld, C: TYLCV-Mld/CLCuGB, D: TYLCV-IL, E: TYLCV-IL/CLCuGB. F-J, susceptible plants(cv. Monalbo) at 150 dpi. F: healthy plant, G: TYLCV-Mld, H: TYLCVMld/CLCuGB, I: TYLCV-IL, J: TYLCV-IL/CLCuGB. K-O, Resistant plants (cv. Pristyla) at 32 dpi. K: healthy plant, L: TYLCV-Mld, M: TYLCV-Mld/CLCuGB, N: TYLCV-IL, O: TYLCV-IL/CLCuGB.

Figure 2: Height of susceptible tomato plants of the cv. Monalbo, 32 days after infection with TYLCV-Mld, alone or in co-infection with different combinations of DNA satellites.

TYLCV-Mld (TM), TYLCV-Mld/CLCuGA (TM/CA), TYLCV-Mld /OLCBFA (TM/OA), TYLCV-MId/CLCuGB (TM/B), TYLCV-MId/OLCBFA/CLCuGB (TM/B/OA), TYLCVMld/CLCuGA/CLCuGB (TM/B/CA). Heights were measured on 22 to 23 plants per treatment (Table 1, Experiment 1). Plants inoculated with an empty plasmid were used as control. Boxplots with different letters indicate significant differences between treatments (Tukey's test, $\mathrm{p}=0.05$ ).

Figure 3: Accumulation of TYLCV-Mld (A), CLCuGB (B), CLCuGA (C) and OLCBFA (D) in susceptible tomato plants (cv. Monalbo) between treatments.

Plants are infected with TYLCV-Mld alone or in co-infection with different combinations of satellites (Experiment 1, Table 1): TYLCV-Mld (TM), TYLCV-Mld/CLCuGA (TM/CA), TYLCV-Mld /OLCBFA (TM/OA), TYLCV-Mld/CLCuGB (TM/B), TYLCV-Mld/ CLCuGA/ CLCuGB (TM/CA/B), TYLCV-Mld/OLCBFA/CLCuGB (TM/ OA/B).Virus and satellite were quantified with real-time PCR in 17 to 24 individual plants per treatment (see Table 1, Experiment 1). Accumulation values obtained from 11, 18, 25 and 32 dpi DNA extracts are proportional to the copy number of the targeted genomes, and corresponded to normalized fluorescence values extracted from qPCR analyses. Within the boxes, the horizontal line indicates the median value (50\% quantile), the box itself delimits the $25 \%$ and $75 \%$ quantiles, and the vertical lines represent the normal range of the values. Boxplots with different letters indicate significant differences between treatments at each date of sampling (Tukey's test, $\mathrm{p}=0.05)$. 
Figure 4: Comparison of the accumulations of TYLCV-Mld and satellites within plants in susceptible tomato plants of cv. Monalbo, infected with TYLCV-Mld either alone or TYLCVMld with different combinations of satellites. Different letters indicate significant differences between targets in each treatment at each date of sampling (Tukey's test, $\mathrm{p}=0.05$ ).

Figure 5: Accumulation of virus and CLCuGB at 18, 32, 45 and 150 dpi in susceptible tomato plants cv. Monalbo infected with TYLCV-IL (TIL), TYLCV-Mld (TM), TYLCV-IL /CLCuGB (TIL/B) or TYLCV-Mld/CLCuGB (TM/B). Accumulation values were obtained from 12 to 20 plants per treatment (see Table 1, Experiment 3). Accumulation values and boxplots are as in Fig. 3. Small letters indicate significant differences between targets within a treatment at each date of sampling; capital letters indicate significant differences of virus accumulation between TM and TM/B or TIL and TIL/B at each date (Tukey's test, $\mathrm{p}=0.05$ ). Differences of mean accumulation values of betasatellite between TM/B and TIL/B were significant only at $150 \mathrm{dpi}$.

Figure 6: Accumulation of TYLCV-Mld and CLCuGB at 18 and 32 dpi in tomato plants of the $T y-1$ resistant cv. Pristyla and a susceptible isogenic line infected with TYLCV-Mld (TM) or TYLCV-Mld/CLCuGB (TM/B). Accumulation values were obtained from 15 to 21 plants per treatment (see Table 1, Experiment 4). Accumulation values and boxplots are as in Fig. 3. Small letters indicate significant differences between targets within a treatment at each date of sampling; capital letters indicate significant differences of TYLCV-Mld accumulation between TM and TM/B treatments at each date and for each cultivar (Tukey's test, $\mathrm{p}=0.05$ ). Differences of mean accumulation values of TYLCV-Mld between susceptible and resistant cultivars were significant at each date and for each treatment. This also applies to the betasatellite.

Figure 7: Accumulation of TYLCV-IL and CLCuGB at 18, 32, 45 and 150 dpi in tomato plants of the $T y-1$ resistant cultivar Pristyla and a susceptible isogenic line infected with TYLCV-IL (TIL) or TYLCV-IL/CLCuGB (TIL/B). Accumulation values were obtained from 10 to 13 plants per treatment except at 150 dpi where 4 and 9 plants were analyzed for TIL and TIL/B treatments respectively (see Table 1, Experiment 5). Accumulation values and boxplots are as in Fig. 3. Small letters indicate significant differences between targets within a treatment at each date of sampling; capital letters indicate significant differences of TYLCVIL accumulation between TIL and TIL/B treatments at each date and for each cultivar 
(Tukey's test, $\mathrm{p}=0.05$ ). Differences of mean accumulation values were significant between susceptible and resistant cultivars at each date and for each treatment for TYLCV-IL and only at 32 and 45 dpi for the betasatellite. 


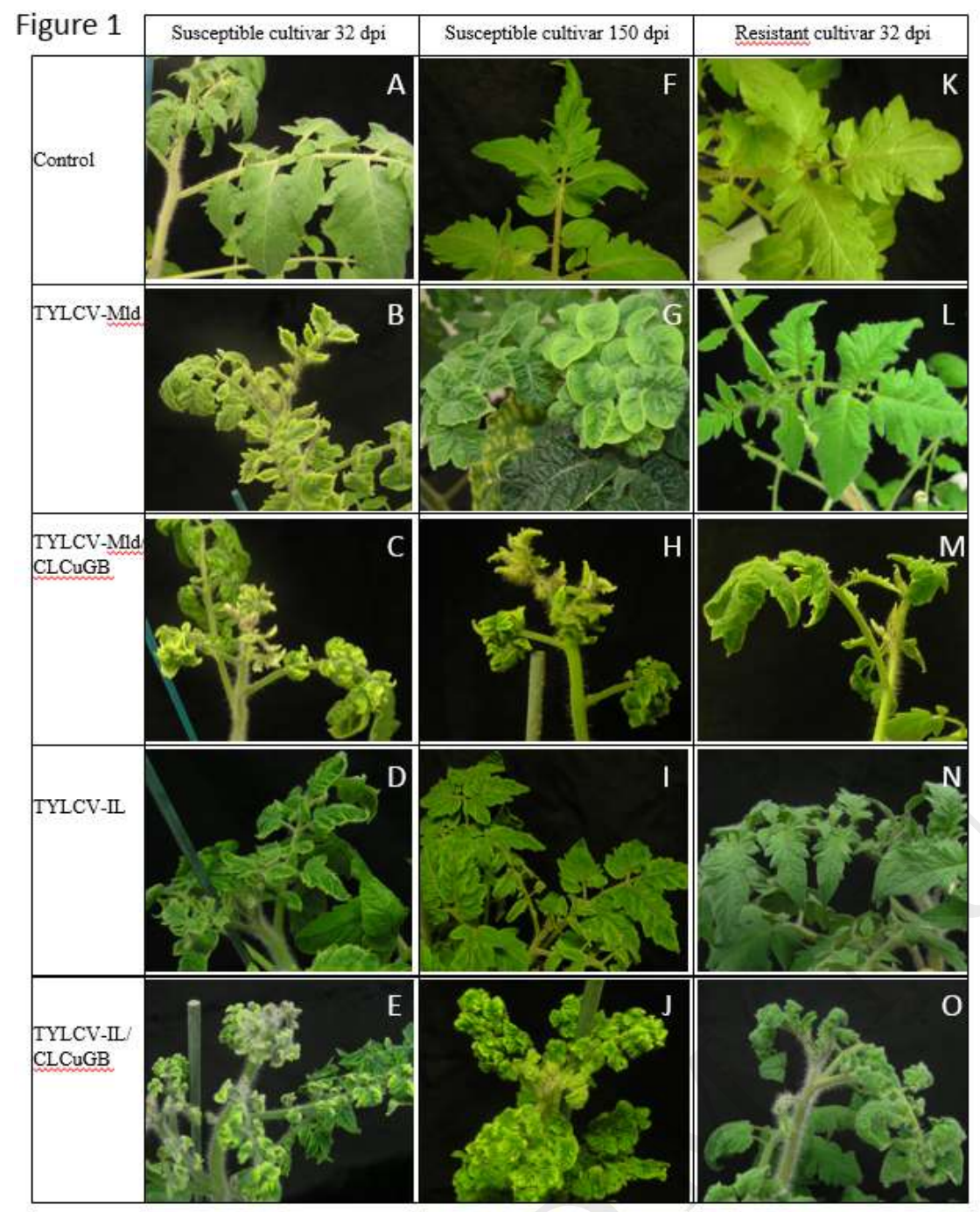


Figure 2

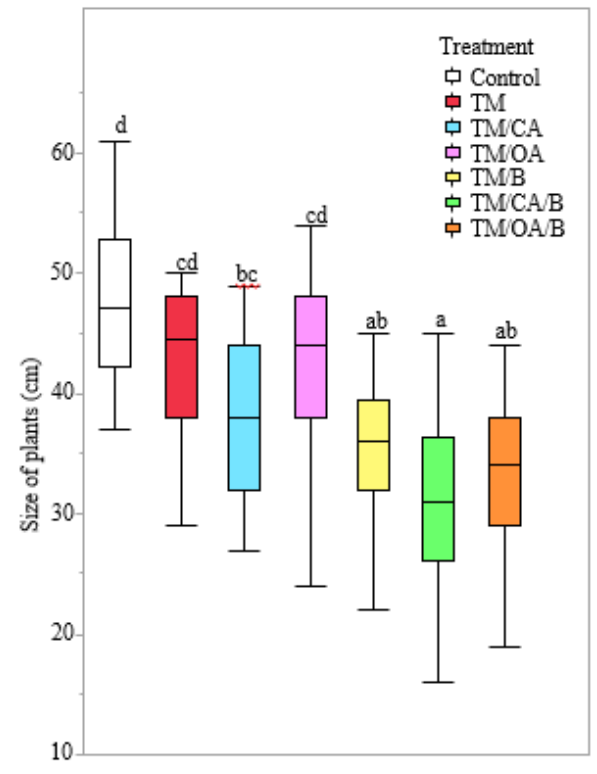

Comment citer ce document: 
Figure 3
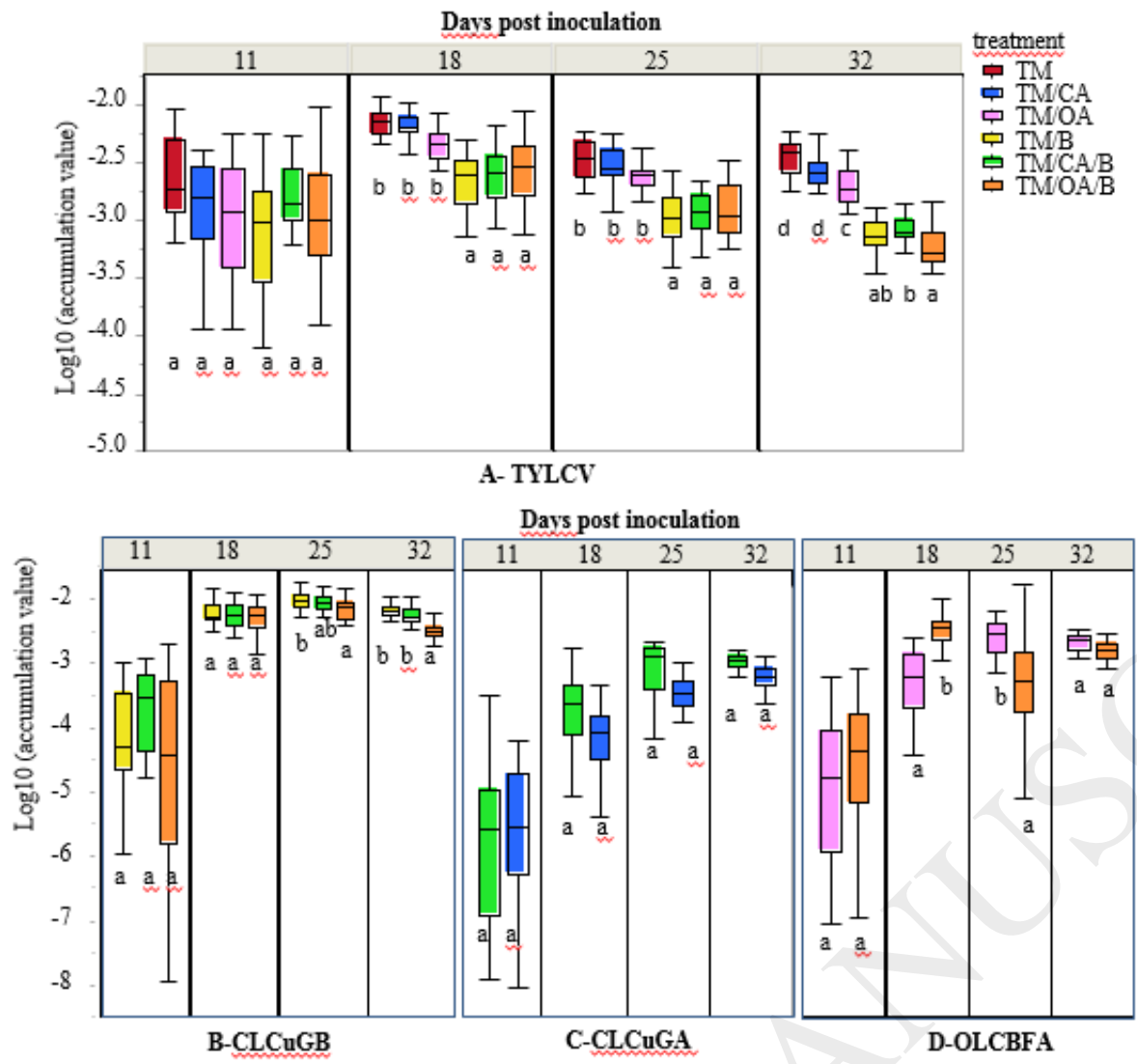
Figure 4
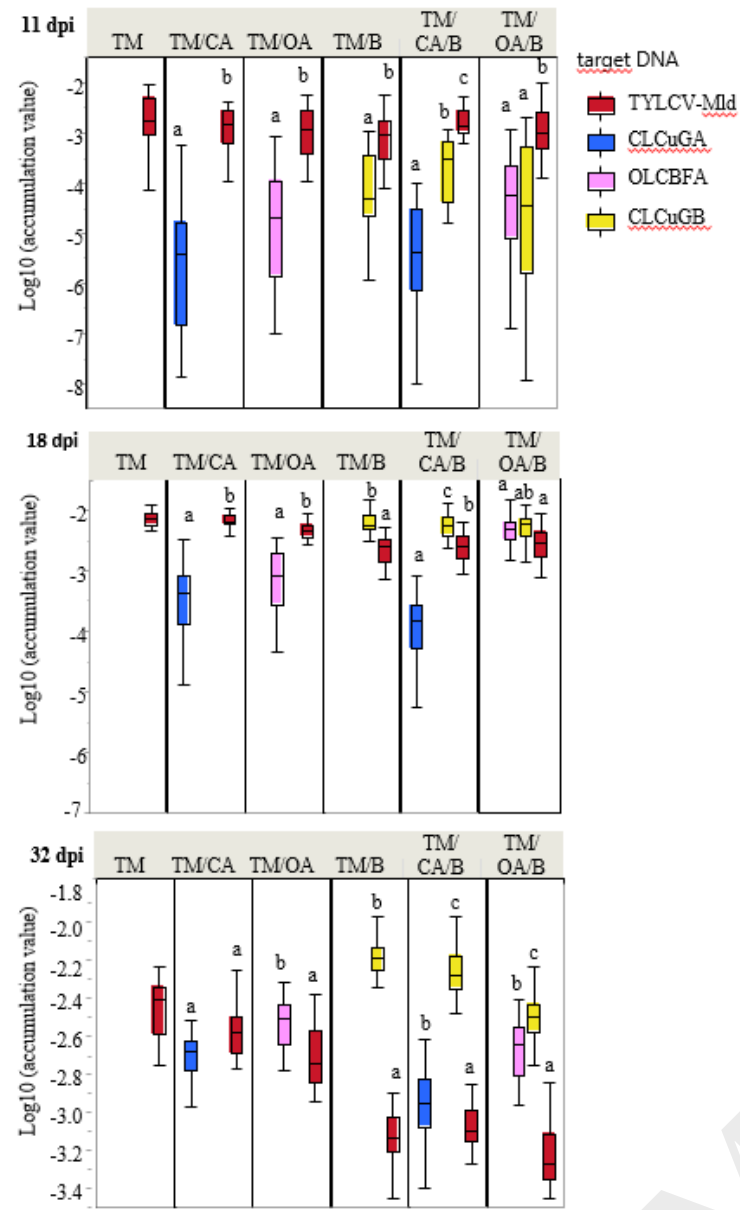

Figure 5

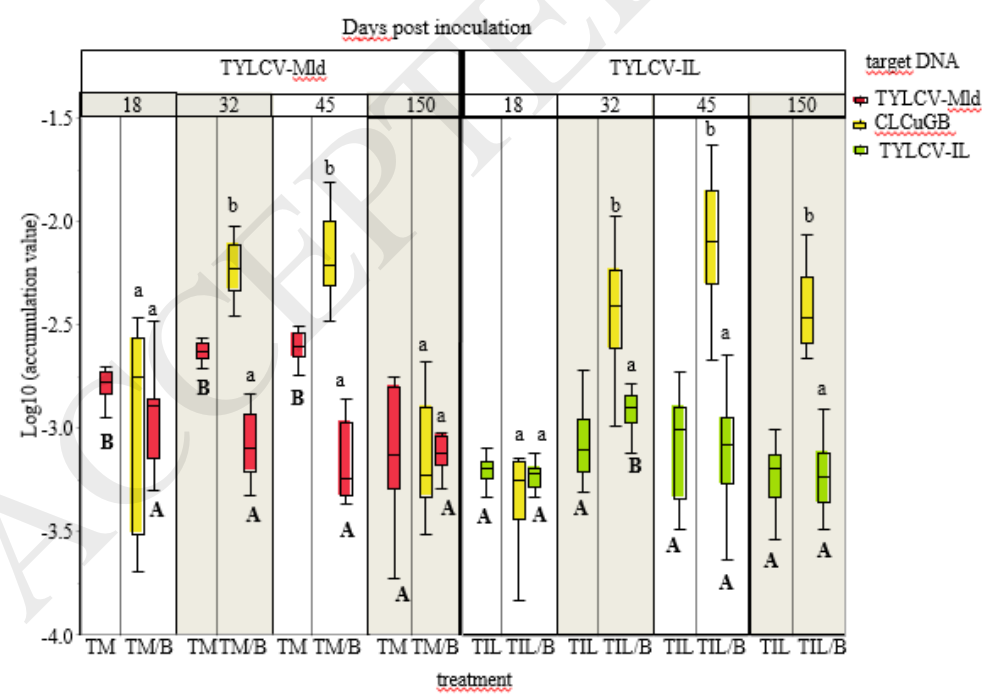




\section{Figure 6}

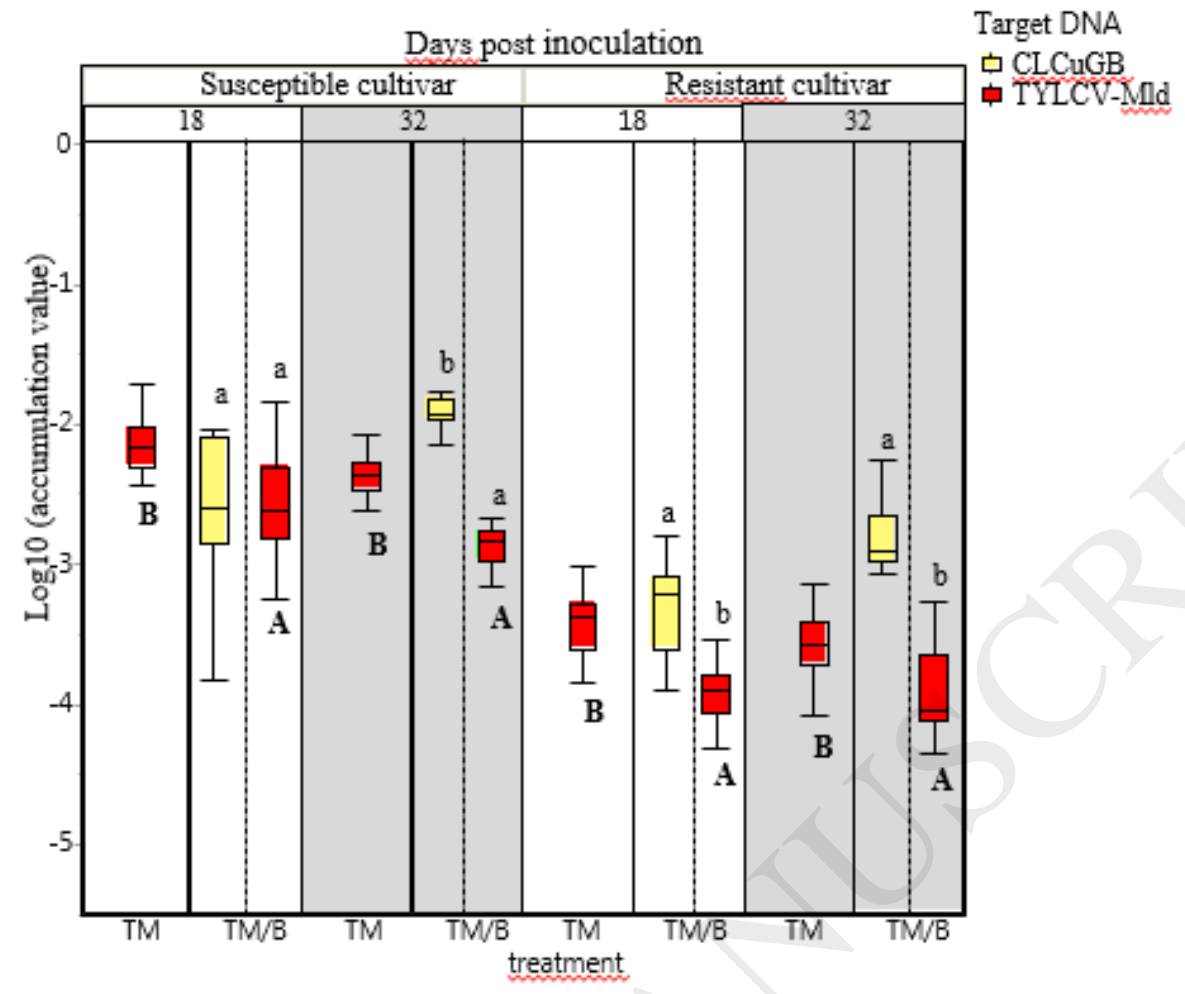


Figure 7

Analysis with No values
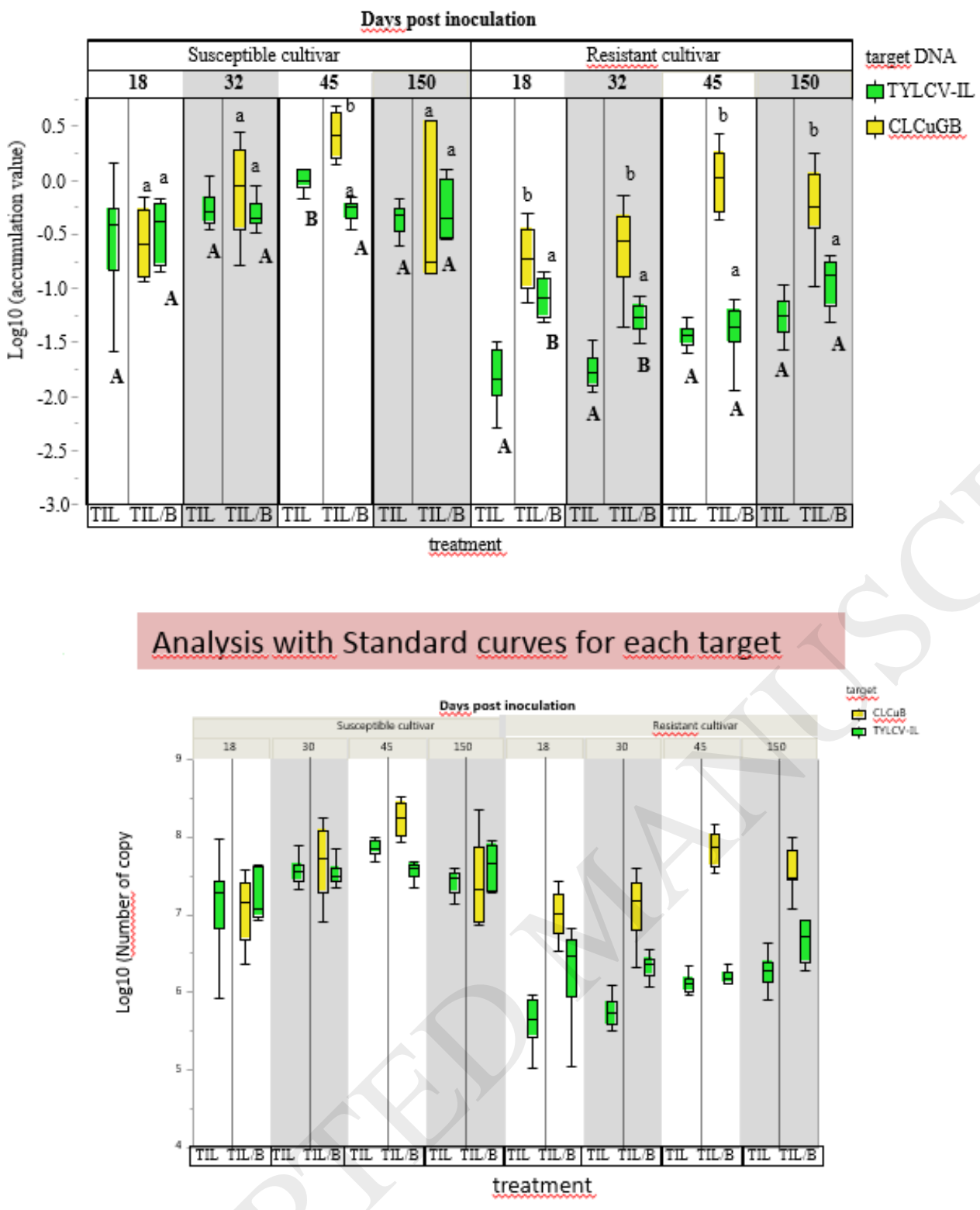


\section{Table}

Table 1: Number of test plants analyzed per treatment in the different experiments

Samples were collected from tomato plants of the susceptible cv. Monalbo, of the Ty-1resistant cv. Pristyla, heterozygous for the $T y-1$-resistant allele $(T y-1 /$ ty-1), and of a susceptible nearly isogenic cultivar (ty-1/ty-1). The agroinfectious clones used in this experiment were TYLCV-Mld (TM) or TYLCV-IL (IL), in single or mixed infection with CLCuGB (B); CLCuGA (CA) or OLCBFA (OA). dpi: days post-inoculation.

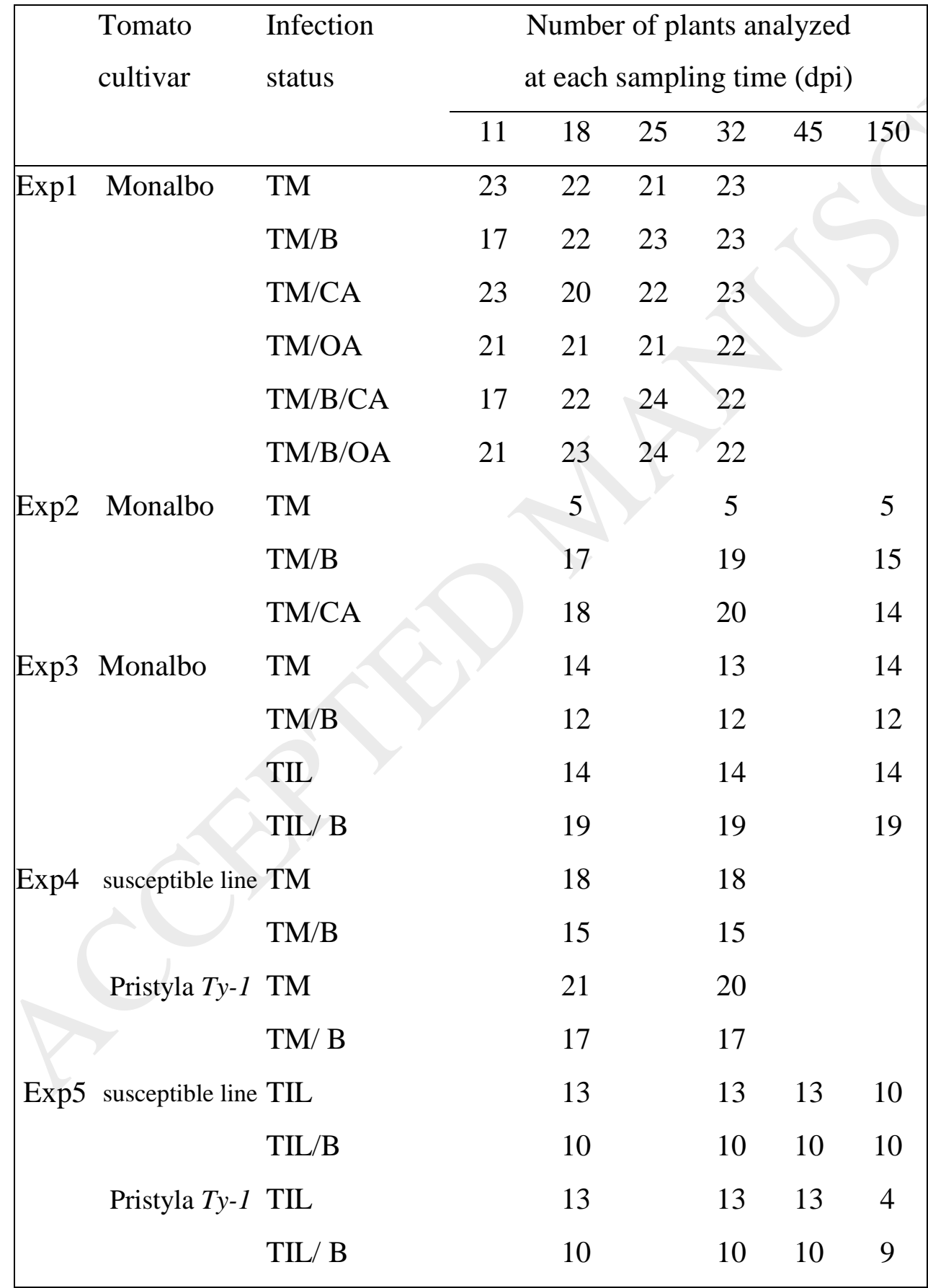

